\title{
The Union Defence Force Between the Two World Wars, 1919-1940 ${ }^{1}$
}

\section{Ian van der Waag}

South Africa was ill prepared for the Second World War. Her war potential was limited and Hitler is reputed to have laughed when the South African declaration came on 6 September 1939. The Permanent and Active Citizen Forces were under strength: the first comprised only 350 officers and some five thousand men. There were a further 122000 men in the Commandos, of whom only 18000 were reasonably equipped, and, being rurally based and overwhelmingly Afrikaans, many of these men did not support the war effort. Furthermore, training and training facilities were inadequate, there was a shortage of uniforms and equipment and, like the rest of the British Commonwealth, much of the doctrine had not kept pace with technological developments. This predicament developed over the preceding twenty years.

The mechanisation of ground forces and the application of new technology for war contrasted sharply with developments in Europe. Although South Africa had the industrial capacity for the development of armour and mechanised forces, arguments based upon the nature of potential enemy forces, poor infrastructure and terrain inaccessibility combined with government policy and financial stringency resulted in nothing being done. Southern Africa, the focus of South African defence policy, was also thought to be unfavourable for mechanised warfare. Inadequate roads and multifarious geographic features concentrated energy on the development of the air arm for operations in Africa and a system of coastal defences to repel a sea assault, as well as a mix of British and Boer-type infantry supported by field artillery. As a result, an expeditionary force had to be prepared from scratch and the first South Africans to serve in the Second World War only left the country in July 1940. Yet the close relationship between the projected role of the Union Defence Force (UDF) and the low priority given to force maintenance and weapons acquisition has been perceived by few writers.

\section{World War I and its lessons}

After 1919, matters had to return to normal. For the South African department of defence and the Union Defence Force this was a misnomer. South Africa was practically at war - the abnormal - from the very establishment of the Union Defence Force in July 1912: industrial unrest in 1913 and 1914, a rebellion in 1914, and then the

Unless otherwise stated, all of the archival material is in the custody of the Military Archives, Pretoria. 
several campaigns of the First World War. Sir Roland Bourne, the Secretary for Defence, could say with some justification in 1921 that, after almost ten years, "only now ... we begin our normal function, the preparation for war."2

The official history, published anonymously in 1924, sketched the complex of divergent campaigns undertaken by the fledgling force. Operations commenced for the purpose of neutralising the radio stations in the German colony of South West Africa. This campaign was suddenly suspended, while attention was diverted to the Afrikaner rebellion. When this was put down, the South West campaign recommenced. An infantry brigade helped quash the Sanusi in Egypt before being practically annihilated in France. The brigade had to be reconstructed more than once. Two brigades of heavy artillery, a signal company, a railway company, an Auxiliary Horse Transport Company and a South African Native Labour Corps also served in France but not in association with each other or the infantry brigade. A large South African force broke German resistance in East Africa; while a brigade of field artillery and later the Cape Corps served in Egypt and Palestine. Numerous South Africans were recruited into the Royal Air Force; others volunteered for service in Imperial units; and all the while the conquered territory of South West Africa was garrisoned by occupation troops, who, in the words of the official historians, "have a successful little native campaign of their own." 3

More than a quarter of a million South Africans served on the different fronts: involving nearly $10 \%$ of the total white population and some $20 \%$ of the male white population. More than thirty thousand South Africans experienced the horror of trench warfare on the Western Front. As a result, the government wished to avoid such loss of life in future and confine future operations to the continent of Africa. Politicians of all hue were determined not to send South Africans into 'the trenches' again. As late as 1939 , Major General J.J. Collyer, and much of the general staff, did not foresee the eventuality of South Africans fighting in the European theatre again and this was eventually included in the Smuts formula of September 1939. ${ }^{4}$ The campaigns in German South West and East Africa, on the other hand, were, as John Buchan noted, "frontier wars, fought for the immediate defence of her borders and her local interests." ${ }^{5}$ Sub-Saharan Africa was

Abridged Annual Report of the Department of Defence for the Year ended 30 June 1921 (Government Printer: Pretoria, 1922), p 1.

Anon., The Union of South Africa and the Great War: Official History (Government Printer: Pretoria, 1924). Although, Wyndham and Collyer, and possibly Smuts, all made contributions, Leipoldt did the lion's share of the work. Jan Ploeger came to a similar conclusion in 1989 , although he unfortunately did not present his evidence. See J. Ploeger, 'Suid-Afrikaanse Staatsen Staatsondersteunde Militêre Geskiedskrywing, 1924-1987', Militaria 19(4) 1989, p.19.

J.C. Smuts, Groter Suid-Afrika; Planne vir 'n beter wêreld (Waarheidsleër: Johannesburg, 1941), p 122.

J. Buchan, The History of the South African Forces in France (Battery Press: Nashville, 1992), p 260. 
South Africa's backyard and the only theatre to which post-1924 governments would even consider sending South African troops.

Several military publications were produced in South Africa between the two world wars. These included several drill manuals and textbooks ${ }^{6}$ as well as the official history of the Great War, which appeared in 1924. The last, described by Agar-Hamilton decades later as having "no outstanding merit", 7 was a global history and must have been a tremendous disappointment to Collyer. He had envisioned a utilitarian history and, although he had stressed the importance of the project "from [a] General Staff point [of] view", 8 the final product drew few lessons.

John Collyer (1870-1941) was a nineteenth century soldier. He began his military career with the Cape Mounted Riflemen and saw action in the Second AngloBoer War as well as the two African campaigns of the First World War. He retired as Chief of the General Staff in 1920, when he embarked upon his histories of the South West and East African campaigns, ${ }^{9}$ which received official sanction in 1936. The pointing out of 'mistakes' was the most important of several motives that prompted the writing of these works. ${ }^{10}$

As far as Collyer was concerned European textbooks were irrelevant in Africa and, in the case of the first, he set about producing a standard text on warfare in East Africa, deducing the 'lessons' in the nineteenth-century utilitarian, didactic fashion: very much in line with Major General 'Boney' Fuller and counterparts in the British Army. Aimed at instruction for officers at the Military College, it was intended to prepare South African officers for service on 'the continent of Africa." ${ }^{11}$ Although, many of his 'lessons'

In 1921 "UDF Infantry Training, Part I (Drill) and Part II (Field Operations"; "UDF Field Artillery Training"; UDF Musketry Regulations"; a revision of "Mounted Riflemen Training"; "Tactical Notes for Officers; and "Notes on Field Sanitation" were in the process of preparation.

J.A.I. Agar-Hamilton, The Union of South Africa War Histories' in Robin Higham (ed.), Official Histories; Essays and Bibliographies from around the World (Westport, 1970), p 443.

Personnel Archives and Reserves (hereinafter PAR): Leipoldt's personnel file. Collyer - Hirsch, 4 Feb 1919.

The Campaign in German South West Africa, 1914-1915 (Pretoria, 1937) and The South Africans with General Smuts in German East Africa, 1916 (Pretoria, 1939).

I. van der Waag, 'Contested histories: Official history and the South African military in the twentieth century'. Paper delivered at a Workshop on Official Histories, School of History, University of New South Wales (Australian Defence Force Academy), Canberra, 1 Oct 1998.

Preface in J.J. Collyer, The South Africans with General Smuts in German East Africa, 1916 (Government Printer: Pretoria, 1939). 
were misinformed, they provide a rare insight into inter-war South African military thinking.

Collyer, quite rightly, pointed out that South Africa had not been prepared for war in 1914 and his first call was for the systematic collection and updating of information in Sub-Saharan Africa and 'the teaching of experience.' Hence his emphasis upon military history and military information, which led to the establishment of a military intelligence section in 1923. It was Collyer who tasked Major J.G.W. Leipoldt back in 1918 to write a brief history of the South West campaign and to specifically utilise the captured German documents. He too appointed a Citizen Force captain, M.S.J.C. van Tijen, to translate into English the diaries kept by Von Lettow Vorbeck during the East African campaign. This was completed in South Africa in 1920, passed to the War Office in April 1920 and published later that year as $M y$ Reminiscences of East Africa. ${ }^{12}$ Foreknowledge would lessen the difficulty in gaining strategic surprise; shorten campaigning in tropical Africa; and so limit casualties.

Collyer undoubtedly had a 'sentimental preference' for the mounted infantry, which he described as 'the national military arm of South Africa.' Only mounted troops could be relied upon in Africa. The East African campaign highlighted the disadvantages of mechanisation: without standardisation repairs were impossible, the lack of roads and bridges resulted in congestion and impaired mobility, while formidable terrain caused endless damage and accidents. Collyer reckoned the lack of mobility in difficult terrain, relative independence from supply lines, and cost effectiveness would all ensure the survival of the horse. Furthermore South Africa, he wrote in 1939, should only mechanise "after careful estimation of its limitations as well as of its effectiveness" and if mechanised transport was standardised and available in the quantity needed. ${ }^{13}$ The much maligned 'bush carts' were introduced for the purposes of police action in Africa, after the then Minister of Defence, Oswald Pirow, had "discussed the matter with the Chief of the Imperial General Staff and General von Lettow, the acknowledged master of bushfighting." ${ }^{14}$ Pirow, at Lettow Vorbeck's advice, equipped the army with ox-drawn bushcarts, believing they would provide greater mobility in the African bush; although, interestingly, Lettow-Vorbeck made some argument in his Reminiscences for the replacement of carriers and pack animals by mechanical transport. ${ }^{15}$ The type of intervention undertaken by South Africa in East Africa in 1940 had simply not been

P.E. von Lettow Vorbeck, My Reminiscences of East Africa (Hurst and Blackett: London, 1920). DC, Box 422, file 51204 Translation Von Lettow's Diary. 266-277.

Oswald Pirow, James Barry Munnik Hertzog (Howard Timmins: Cape Town, n.d.), p 219. 
contemplated.

However, Collyer, a mounted infantryman with fifty years of service in Africa, was clearly not a man for modern devices. With regard to air power, for example, he predictably highlighted the problems rather than possibilities: "So far as the enemy troops were concerned, aerial action did little damage and produced trifling information." ${ }^{16}$

Collyer also stressed the strength of the tactical defence in tropical bush country. Invoking Clausewitz, he called for a defence so arranged that full use could be made of the counterattack. And here South Africans seemingly lacked. "Training", he said, "should aim at mobility and flexibility with an organisation calculated to confer the maximum possible of these necessary conditions." Furthermore, training for the counterattack was essential. The Boers lost a succession of opportunities during the gambits of the Anglo-Boer War, largely from a failure to recognise the value and the opportunity for the counterattack. The idea that defence need accomplish no more than the repulsion of an enemy needed addressing. The South African needed greater moral fibre, more aggressiveness on the battlefield, a willingness of sustain casualties, and a determination to defeat the enemy and not just repulse him. ${ }^{17}$

\section{Demobilisation, rationalisation and reorganisation}

The First World War officially ended on 11 November 1918. A peace conference, arranged to settle the new world order, opened in Paris ten weeks later; and all of the Allied and Associated Powers, including the Union of South Africa, were present. The South African generals, Louis Botha and Jan Smuts, fought for the mitigation of the sentence passed particularly against Germany but were equally determined to obtain possession of German South West and German East Africa - the enemy territories which the Union had conquered and occupied. However, in the end, they walked away with considerably less: a mandate was granted over South West Africa only. ${ }^{18}$ Decades later, South Africa's trusteeship over this territory was disputed; and this eventually led to an extended bush war in Namibia and Angola.

Botha returned from Paris in July 1919, tired bothphysically and mentally. He died suddenly on 27 August 1919, and Smuts, Minister of Defence and for so long heir apparent, became the new prime minister. His was the task of rationalising the Union Defence Force from its war-inflated strength to more or less its pre-war status. The First

J.J. Collyer, The South Africans with General Smuts in German East Africa, 1916, p 87. 273. 
World War placed an enormous burden on South Africa, having cost some $£ 31 \frac{112}{2}$ million. ${ }^{19}$

After 1918, South Africa followed a policy of strict economy and retrenchment. Although the Active Citizen Force regiments raised during the German Southwest campaign were already demobilised in $1917,{ }^{20}$ most of the temporary wartime units were disbanded with effect from 31 December 1919. During this process, most of the volunteer units that had served so meritoriously during the First World War were disbanded or demobilised. Of all the engineer units, only the Cape Fortress Engineers remained to maintain the defence electric lights (searchlights) and telephone equipment in the Cape Fortress. ${ }^{21}$ By July 1919, the SAMC units of the Active Citizen Force had ceased to exist, the Medical Training School was closed and an ever decreasing number of personnel were serving at the various hospitals in the Union and in the Protectorate. As the demobilisation proceeded, the number of medical officers was further reduced until sufficient medical support remained for the requirements of only one or two mounted regiments. ${ }^{22}$

The six Military Districts were amalgamated into three. The Chief of the General Staff assumed the functions of the Commandant of Cadets in 1919 and three years later the work of the Secretary for Defence. The post of Inspector General was abolished on 30 November 1921, when the Adjutant General took over the work of that section. The return of civilian rule to South West Africa also had its effect on the size of the Union Defence Force. Two mounted regiments of Military Constabulary together with the Protectorate Garrison Regiment were disbanded on 30 June 1920 and replaced by a civilian police force called the South West African Police. ${ }^{23}$ The remainder of the troops arriving back in the Union were all demobilised. Yet, this process was barely over, when new realities emerged.

In many ways 1921 was a watershed year in the history of the Union Defence

Archives of the Secretary for Defence (hereinafter DC), Box 1152, file DB 2443/Z Union War Expenditure; and F.J. Jacobs, 'Tussen twee wêreldoorloë' in R.J. Bouch (ed), Infantry in South Africa, 1652-1976 (Pretoria 1977), pp 127-128.

DC, Box 254, file 17767 Dishandment of Temporary Citizen Force Units and disposal of temporary officers.

N. Orpen and H.J. Martin, Salute the Sappers, I: The formation of the South African Engineer Corps and its operations in East Africa and the Middle East to the Battle of Alamein (Sappers Association: Johannesburg, 1981), p 8 .

DC, Box 1411, file 70038 Reorganisation of the Department (Medical Section). Director Medical Services - Secretary for Defence, 31 Jul 1919.

DC, Box 412, file 50913 Police Force for the Protectorate SWA, Disposal of the Military Constabulary; and Proclamation 21, Official Gazente of the Protectorate of South-West Africa in Military Occupation of the Union Forces(No 25 of 24 Dec 1919). 
Force. Much happened on both the local and international fronts and the Union Defence Force, if it was to continue to play a significant role had to keep abreast of these new developments. Fluctuating circumstances demanded change, and this filtered through the Union Defence Force to its various components. The main developments which lead to the reorganisation which took place in the Union Defence Force in the early twenties, were the withdrawal of the Imperial garrison from South Africa in 1921; the concomitant transfer of all War Office and certain Admiralty property in South Africa, to the Union Defence Force during 1920 and 1921; and the identification of new threats at the 1921 Imperial Conference, which had the potential to immediately risk the security of the Union, or jeopardise Imperial interests locally and abroad. Such flashpoints were indeed witnessed in 1922 (see below).

The continued presence of a British garrison in South Africa was a politically loaded question and related to the whole issue of demobilisation. Smuts believed the return of an Imperial garrison to be unnecessary after the war. After all, between 1914 and 1918, South Africa had proven herself not only to be loyal, but also capable of defending herself. Furthermore, Imperial defence had to be reconsidered in the light of the new conditions brought about by the war, and particularly by the defeat of Germany and the removal of the menace previously associated with the German colonies. An attack on the Cape defences was even more unlikely than it was prior to the outbreak of war in 1914. Defensive measures against a sea-borne attack were unwarranted and in view of the absence of an immediate external threat, Smuts believed that the return of the garrison to South Africa would be a clear indication that Britain did not fully trust the loyalty of her South African subjects.

Toward the end of 1920 , the decision, for so long pending, to withdraw the Imperial garrison in its entirety, was finally taken in London and what was called the South African Military Command was closed on 1 December $1921 .^{24}$ As a result, most of the cantonments and defences belonging to the War Office and the Admiralty were handed over to the Union Defence Force. The poor state of many of these buildings and the need for an efficient maintenance organisation to undertake the work proved cardinal to the establishment of the SA Engineers Corps in $1923 .^{25}$

In terms of national defence, the climate had also changed considerably. After 1918, the only immediate threats to the security of South Africa was the internal unrest that manifested in periodic 'native uprisings' and the industrial trouble which finally erupted with force in January 1922. The former had occurred almost annually since the

DC, Box 886, file Q.23892 Transfer South African Military Command to Union Defence. Secretary for Defence - Headquarters, SA Military Command, 28 Sep 1921. 
disturbances at Grahamstown in April 1917. They clearly underlined the important role the Defence Rifle Associations and later the Commandos, had to play in territorial defence when the Permanent and Citizen forces were otherwise deployed. ${ }^{26}$

\section{The test: deployment locally and abroad}

Black people lacked the means to oppose the growth and monopolisation of military power in South Africa by people of largely European descent. The Union Defence Force was all-white and the more than twenty thousand blacks who served in the Great War largely did so as unarmed labourers. The exception was found in the eighteen-thousand-strong Cape Corps, who served meritoriously in East Africa and Palestine, only to be disbanded in the face of political pressure. However, resistance was impaired not only by lack of access to modern weapons and training but also by cultural and historical differences. Despite white fears, the chance of a general rising was remote. The chiefs, in awkward suspension between state-responsibility and community support, did not co-operate militarily and when one fell foul of the law he almost invariably faced the state as an individual. ${ }^{27}$

When traditional or religious leaders challenged the state, lack of co-operation and modern weaponry brought a predictable result. With the Israelite Rebellion of May 1921, the Union faced perhaps one of the more serious of these so-called 'disturbances' of the decade. The UDF provided half a battery of artillery, a medical officer, motor ambulance and a stretcher party in support of the South African Police. ${ }^{28}$ In the end, no use was made of the artillery and the attack was repulsed by rifle and machine gun fire with considerable loss to the Israelites: 167 dead, 132 wounded and some 100 captured. ${ }^{29}$ The Police casualties were one man stabbed in the stomach, one man cut over the hand and one horse killed. ${ }^{30}$ Superior weapons clearly decided the day, with no use even made of the UDF.

The Bulhoek incident had, nonetheless, caught the security forces off guard. The Defence Department had made no budgetary provision for military emergencies and

DC, Box 1025, files DF 4/573 Native Disturbances Natal 1919; DF 5/573 Native Trouble at Rustenburg; and DF 6/573 Industrial and Native Unrest in the Transvaal.

K. Grundy, Soldiers without Politics; Blacks in the South African Armed Forces, pp 48 et seq.; and L. Thompson, A History of South Africa (YUP: New Haven and London, 1990), pp 170-172.

DC, Box 451, file 52002 Recalcitrant 'Israelite' Natives. Superintendent of Natives - Magistrate Queenstown 23 August 1920. 
certainly not for police duties. ${ }^{31}$ In fact, in November 1920, as the problem at Bulhoek was developing, Brigadier-General A.J.E. (Andries) Brink, then Chief of the General Staff, submitted proposals to reorganise the Permanent Force and replace the South African Mounted Riflemen with a combat worthy and mobile force of $2500 .^{32}$ However, financial considerations scuttled the idea. In May 1921, the UDF could not provide military assistance to the Police in excess of 150 to 200 SAMR details. Beyond this and a small garrison of SAMR, and 450 Returned Soldiers, the UDF had no troops available to assist the Police in maintaining order. The troops at Cape Town could, in any case, not be removed from the Cape Peninsula except in the event of a very serious emergency. The only other option was to call out the Citizen Force by proclamation, ${ }^{33}$ as happened in 1922 to quell the Rand Strike.

By the early twenties, two other threats to white South Africa came to the fore. The first of these was a strong flare in Pan-Africanism, which presented the potential danger of a general African uprising against European rule on the continent at large. The second was a war between the United Kingdom and a European power that maintained a native army in Africa.

In terms of the second scenario, South Africa could find herself drawn into an African war involving the colonies of two or more European powers entangled in a war in Europe. Whereas South Africa, like other British territories on the Continent, followed a policy of disarming all black Africans, the French, Belgian and Portuguese colonial administrations openly militarised vast numbers of their colonial subjects. By 1926 , Force Publique of the Belgian Congo numbered 16650 troops under a white leadership of only $450 .^{34}$ (By comparison, there were only 168 Permanent Force officers in the Union Defence Force in 1923, and this included officers seconded from the Imperial forces.) ${ }^{35}$ The problem of defence, therefore, no longer remained confined to disturbances within the Union, but embraced happenings in the greater part of the continent of Africa. $^{36}$

DC, Box 451, file 52002 Recalcitrant 'Israelite' Natives. Secretary for Defence - Secretary for Finance, 25 Aug 1921.

DC, Box 378, file 40309 Reorganisation Artillery. Chief of the General Staff - Financial Under Secretary, 18 Oct 1920.

Issued under Section 79 of the South Africa Defence Act (Act 13 of 1912).

Archives of the Deputy Chief of Staff (hereinafter DCS), Box 3, file SP 9 Capt Theron's attachment to War Office. Information extracted from War Office, Admiralty and Air Force files by Capt F.H. Theron during his attachment - Sept 1929; and Report on "Belgian Military Forces in Congo; Extract from Report of Colonial Ministry."

Abridged Annual Report of the Department of Defence, Union of South Africa, for the Year ended 30 June 1923 (Pretoria 1924), p.13. 
Furthermore, the British, tied down in various parts of the world, had become involved in a number of military operations, which not only hardpressed the taxpayer but stretched to the maximum the deployment of her overseas forces. Britain therefore planned to delegate certain of her military responsibilities to the Dominions during the 1921 Imperial Conference. Although the War Office did not expect a major war for the next five to ten years, they were anxious that each Dominion give an indication of the maximum strength they could send in an emergency. The Dominions were equally reluctant to make unconditional commitments. The War Office, however, stressed that it was not intended that the Dominions should surrender in advance their discretion as to whether they will undertake any particular operation at any particular time, since their action would necessarily depend on the political circumstances when the emergency arose. Furthermore, time and geography, could make Dominion contribution vital as these troops, in some cases, could reach theatres of operation thousands of kilometres away from Europe, weeks before the arrival of British troops.

Although the chief concerns of the 1921 Imperial Conference included the problem of the Anglo-Japanese alliance and relations between Britain and the Dominions; the question of Imperial defence was the most vital. Previous attempts at Imperial defence planning had failed. The Committee for Imperial Defence, formed in 1902 in the wake of the Anglo-Boer War, was purely advisory and achieved little. An Imperial General Staff was established in 1907 but the Dominions refused to make any definite commitments. While in 1911 Canada and South Africa shot down a New Zealand-sponsored proposal for an imperial defence council; although this did not prevent Louis Botha from accepting a general's rank in the British Army a year later! ${ }^{37}$

The Conference also aimed to implement a number of general measures. These included the co-ordination of military thought throughout the Empire by means of regular liaison letters and exchanges of personnel for military courses. The standardisation of establishments and equipment, manpower distribution schemes, the supply of war-like material, and the collection and co-ordination of intelligence was also discussed. ${ }^{38}$ However, as Martin Kitchen has pointed out, "to keep the Empire together Britain had to [be] tolerant and reasonable. ${ }^{39}$ The training of South Africans

at Woolwich, Cranwell and Dartmouth had little impact. They were too few - the quotas could not be maintained due to problems passing both the literacy and physical tests in

Reorganisation UDF, Vol II. Enc 1 South African Defence Policy by CGS, 20 Sep 1933.

A.H. Marais (red.), Politieke Briewe, 1911-1912 (Tafelberg: Kaapstad en Johannesburg, 1973), pp 99-106. Defence, 19 May 1921, and appendices.

M. Kitchen, The British Empire and Commonwealth: a short history (Macmillan: Basingstoke and London, 1996), p 59. 


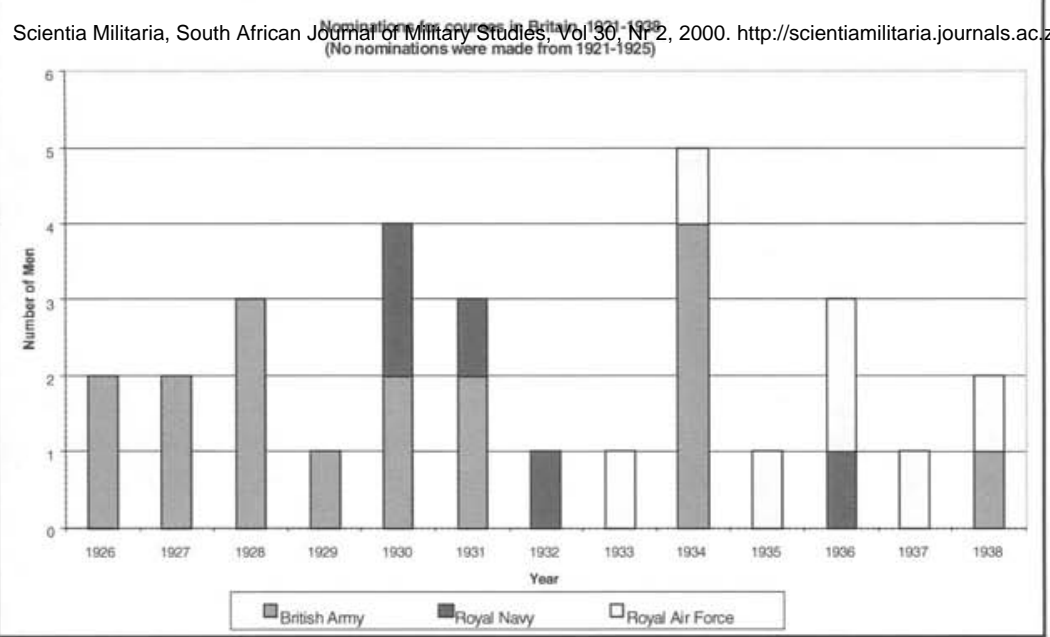

South Africa ${ }^{40}$ - and most of those that did were subsequently seconded to the British forces (figure 1). There were exceptions: most notably George Brink (1889-1971) and Dan Pienaar (1893-1942). Major General Dan Pienaar, hero of the Abyssinian campaign and commander of the $1^{\text {st }}$ Division at Alamein, attended several arms courses in the United Kingdom and lectured gunnery and mapping at the Military College in the 1920 s. $^{41}$

The creator of the South African expeditionary forces and first commander of the $1^{\text {st }}$ Division, Lieutenant General George Brink, was a classmate of Bernard Montgomery, Bernard Paget and Richard OConnor and reckoned Camberley to have been of 'inestimable value.' $\mathrm{He}$, his biographer tells us, "was assiduous in assimilating data on military organisation and administration. He continued to study on his own. To the end of his life his reading, apart from newspapers and periodicals, consisted largely of political and military history. ${ }^{.42}$ Brink became Chief Instructor, Tactics at the Military College after the Rand Revolt, a position he held for nine years. There he influenced the Permanent Force and Active Citizen Force officers, from whose ranks the Second World War leadership came. Under his guidance, junior officers studied the art of war at the tactical level, while senior officers deliberated on the command and logistics of larger formations. Commissioned by the pre-war defence minister, Oswald Pirow, Brink went on a study visit to Europe in 1937. There he studied the British armed forces, those of France and Italy, the potential enemies in Africa, and, above all, Germany. Brink

Abridged Annual Report of the Department of Defence for the Year ended 30 June 1921 (Government Printer: Pretoria, 1922), p 4.

A.M. Pollock, Pienaar van Alamein; Die Lewensgeskiedenis van 'n Groot SuidAfrikaanse Soldaat (Cape Times: Kaapstad, 1943), pp 15-20. 
returned brimming with ideas soon to revitalise the Union Defence Force. ${ }^{43}$ His zeal and progressive spirit is impressive, particularly when seen against the gloomy background of the era.

South Africa in 1921 recognised an obligation to contribute on a more equitable basis to the naval requirements of the Empire. ${ }^{44}$ Until then she maintained no permanent naval forces but made annual cash contributions of $£ 85000$ to the Admiralty. These now ceased and South Africa developed a naval capability. The South African Naval Service was established in 1922, following the donation of the HMS Thames, an obsolete light cruiser of 4050 tons that had been used as submarine depot and repair workshops in the Medway. This was renamed the "General Botha Memorial Training Ship." ${ }^{45}$ A minesweeping section and a war reserve section were organised; while the Royal Naval Volunteer Reserve was increased from 309 members in 1921, to 750 a year later, reaching a peak of 857 in 1933. The South African Naval Service (SANS), a permanent naval force, was established in 1922, with officers and ratings to man the minesweepers and also to train the RNVR personnel. ${ }^{46}$ South Africa also agreed to undertake the hydrographic survey of South African waters, pay the cost of certain workshop developments in the East Dockyard at Simon's Town (actual cost of $£ 192$ 188) and provide for the erection and initial filling of two oil tanks (actual cost $£ 123179$ ). ${ }^{47}$

South Africa furthermore accepted the responsibility of colonial policing in southern and central Africa. She could, it was thought, raise a force of sufficient strength to deal with any rising south of the Zambezi and by the end of the Conference, South Africa had in effect accepted responsibility for the ultimate restoration of order in southern and central Africa should the local colonial forces fail. ${ }^{48}$ The air arm was considered most effective for financial and moral reasons and, despite the policy of strict economy that was applied immediately after the War, a South African Air Force (SAAF) was established. ${ }^{49}$ Smuts had spent a good portion of 1917 in London, where he drafted

C. Birkby, Uncle George, pp 71-72,87-91.

DC, Box 1929, file 335/1 Imperial Conferences. Prime Ministers' Conference in London 1921; and 'The Empire Conference', Cape Times, 21 April 1921.

DC, Box 518, file 52561 S.A. Naval Services Training Ship General Botha. Report of a Committee appointed to make recommendations as to a training ship for preparing South African boys for a seafaring career, 19 Nov 1920.

CGS Gp 2, Box 311, file 437/2 SA Defence Act Amendment Act 1922 Reconstitution of Permanent Force. Chief of the General Staff - Minister of Defence, 19 Jun 1922.

DC, Box 1098, file 4/58X South African Naval History.

CGS Gp 1, Box 356, file 13/40057 Intelligence Service Scheme of Organisation. Major J.G.W. Leipoldt - Chief of the General Staff, 11 Nov 1921.

Government Notice No.17 of 1923 (Supplement of the Union of South Africa Government Gazette No.1289 of 26 Jan 1923), published in terms of section one of the South Africa 
two reports on air warfare. In the second, more seminal report he forecast the role for the new service:

\begin{abstract}
"Unlike artillery, an air fleet can conduct extensive operations far from, and independent of, both armies and navies. As far as can be foreseen, there is absolutely no limit to the scale of its future use, and the day may not be far off when aerial operations, with their devastation of enemy lands and destruction of industrial and populous centres on a vast scale, may become the principal operations of war, to which the older forms of military and naval operations may become secondary and subordinate..."
\end{abstract}

Smuts was a man for gadgets. He liked "the big thing rather than the adequate but unspectacular." 51 The report, with its fantastic concepts and particularly the idea of a separate, autonomous air force, was not well received. Animosity among anti-Boer British officers played a role. With the possible exception of Paardeberg and the Brandwater Basin, the Boers had not been beaten in the field but rather through the weight of manpower and material: something the British either failed to appreciate or refused to admit. ${ }^{52}$ To many a British officer, South Africa was still perceived as the 'beaten enemy' of the Anglo-Boer War. In 1917, while Smuts was expounding his airpower ideas in London, Brigadier-General A.E.J. Cavendish, commander of the South African Military Command, described him as "that modern miracle" whom "for (the) beaten enemy ... had a very nasty knack of asserting himself at times." 53

Nevertheless, despite the opposition and the difficulties posed by climate, obsolete aircraft, inadequate logistic support and financial stringency air policing was applied in South Africa and elsewhere to great effect throughout the inter-war era. And while vocal minorities denounced the application of air power, and particularly against tribesmen, as inhuman and unworthy of civilised nations, poor communications allowed the harsh effects to continue for as long as it did. ${ }^{54}$ The following decade saw South Africa still focussing on the cost effective, Britain upon what was considered more humane. In 1935, the Acting British High Commissioner, Edward Evans, declined a

Defence Act Amendment Act (No 22 of 1922).

As quoted by Michael Armitage, The Royal Air Force; An Illustrated History (Brockhampton: London, 1996), p 27.

Public Record Office, London (hereinafter PRO): Dominions Office (hereinafter DO) 119/1052 High Commissioner for United Kingdom, Pretoria - Secretary of State, London, 17 Jul 1935.

I am grateful to my colleague, Lt Col Deon Visser, for this insight.

DC, Box 1142, file DCDB 2394/ Suggested recall of General Cavendish G.O.C. South African Military Command and appointment of General Martyn.

M. Armitage, The Royal Air Force, pp 50-51. 
South African offer of a bomber for punitive use against the Khama regent at Serowe. ${ }^{55}$ Whereas criticism of "policing dissident tribesmen from the air [attracted] both operational and moral criticism" in the United Kingdom, and brought an expansion in the role of ground forces, this was not so in South Africa, where the air forces retained its novel appeal and special claim on the budget, and had a loud voice in the person of Van Ryneveld. $^{56}$

The establishment of the SAAF and SANS was only made possible by the donation of equipment. The fledgling air force comprised two squadrons of three flights, each flight of six aeroplanes; with a depot, a repair and aircraft parts workshop. The executive commander of this force was Colonel Sir Pierre van Ryneveld, the vainglorious airman knighted after his epic flight from London to Cape Town, who also headed the Air Service Section at Defence Headquarters. ${ }^{57}$

The added responsibilities brought about by the withdrawal of the Imperial garrison and the assignment of the 1921 Imperial Conference placed the Union Defence Force in a dubious position. The tiny post-war defence force was now tasked with the entire defence of the Union, and the suppression of any 'native insurrections' in the Portuguese colonies, Matebeleland, Mashonaland and in the High Commission territories of southern and central Africa - Swaziland, Basutoland, Bechuanaland and Barotseland.

This presented something of a predicament. The Bulhoek incident had revealed severe inadequacies in the Union Defence Force and, in 1921, there was no regular means of gauging the state of affairs to the north of her borders, beyond the information occasionally supplied by the Imperial Secretary. This immediately led to the re-establishment of an Intelligence branch within the office of the Chief of the General Staff on 1 September $1923,{ }^{58}$ and closer liaison with the colonial administrations to the north. $^{59}$

R. Pound, Evans of the Broke; A Biography of Admiral Lord Mountevans (OUP: London, 1963), p 225.

B. Bond. The Army between the Two World Wars 1918-1939' in D. Chandler and I. Beckett (eds.), The Oxford History of the British Army (OUP: Oxford and New York, 1996), p 257.

DC, Box 1104, file R.B.1/040 Organisation of the Air Forces of the Self-Governing Dominions. Sir Roland Bourne - Air Vice Marshal Higgins, 7 Jul 1921.

I.J. van der Waag and L. Jooste, A history of Military Intelligence in South Africa (unpub ms Pretoria 1990), p 13. Although the Intelligence branch was re-established with effect from 1 September 1923, it is interesting to note that General A.J.E. Brink had already requisitioned a car "for Secret Service" in June 1922 (DC, Box 519, file 52579 Secret Service. Chief of the General Staff - Quartermaster General, 14 Jun 1922). 
The situation at home was as bad. The position regarding maps could not have been more unsatisfactory. The UDF lacked maps in respect of more than half of the surface of South Africa itself. Good military maps existed only for the 'old trouble spots', including the Orange Free State, Basutoland and the Kalahari south of the Orange River to latitude 31 degrees. Moreover, no maps suitable for operations were available for practically the whole of the South African coast. ${ }^{60}$ In January 1923, the HMSAS PROTEA commenced survey operations at St Helena Bay. Strategically situated near Cape Town, this bay was identified as the most likely beachhead for an invasion force. ${ }^{61}$ The situation on the interior was only slightly better. By 1921, Major J.G.W. Leipoldt, a surveyor by profession, had surveyed the headwaters of the Okavango and Kwande rivers and the Lunge-Vungo River to within 160 kilometres of the Northern Rhodesia frontier, and was working on the Zambezi waterways. These surveys, although commissioned by the Department of Agriculture, were vitally important to the UDF and the planning for potential war against the Portuguese colonies. ${ }^{62}$

1922 was a watershed year. The Permanent Force was reorganised and infantry, artillery and engineer units were established. This, together with expansion of the Active Citizen Force during the mid-1920s, must be seen against the background of the internal unrest within South Africa and the mandated territory of South West Africa during the first half of the twenties. The uprising at Bulhoek was followedby a se ries of incidents in 1922, and it is therefore not insignificant that 1922 was also the year in which the Defence Act was amended to allow for the reorganisation of the Permanent Force of the Union Defence Force.

The Rand Strike revealed further inadequacies in the UDF. The Permanent Force proved totally inadequate and this necessitated the calling up of not only the Citizen Force, but also the Class A Reserve. Furthermore, when the alarm was received in Roberts Heights, there was "utter confusion due to [the] lack of [a] Brigade headquarters to issue orders". ${ }^{63}$ The orderly officer issued the orders and valuable time was lost in dispatching orders to the individual artillery batteries of the SAMR. It was clear that a Brigade Headquarters with an authority and continuously responsible for the training, administration and discipline of two or more units of the same arm of the

Chief of the Imperial General Staff, 28 Mar 1923.

Gp 1, Box 23, file C/1 Formation of Artillery Brigade Headquarters. Commanding officers of 1st, 2nd and 3rd Permanent Batteries, SAMR - OC Troops, Roberts Heights, 3 Apr 1922. 
Service when stationed and working together, had to be provided for. ${ }^{64}$ An Artillery Brigade Headquarters was actually formed as a result, and was provided for in the 1922 Defence Amendment Act.

The air arm, established under the command of Sir Pierre van Ryneveld in 1920, was very much in line with the ideas mooted by Smuts and Trenchard regarding the use of airpower in the policing of the colonies. It was not only very economic, both in terms of finances and manpower, but also held many other advantages. Airpower was thought to be more humane, decisive, elicited greater fear, and was almost immune to ground attack at the time. This was demonstrated in South West Africa (now Namibia) in 1922, during the suppression of the Bondelswarts tribe. South African ground forces, including two field guns and 100 mounted troops, failed to defeat Abraham Morris and his men at Haib. The Bondelswarts sought refuge in one of their traditional strongholds - the Fish River Canyon - that proved quite inaccessible to their pursuers. Eventually two airmen co-operating with the ground forces forced a surrender within a matter of days. The ground forces were prone to ambush, constantly harassed by enemy raiders and held up in the mountain passes. Demonstration flights over Keetmanshoop put an end to further 'trouble' and the contingent returned to Pretoria as early as 3 July $1922 .^{65}$

A more sophisticated defence force was required. The Rand Strike and the Bondelswarts uprising highlighted the importance of air power; while the latter seemingly emphasised the problems surrounding the deployment of ground troops in unfamiliar, broken terrain. The Defence Act, designed as a temporary measure to bring four disparate colonial defence forces together, was amended in 1922. The amended Act provided for a total reorganisation of the Permanent Force, including the amalgamation of the five SAMR regiments into a single regiment of mounted riflemen. The various forces that constituted the Union Defence Forces were brought under a single Headquarters staff. Provision was also made for an instructional and administrative staff as well as specialised Permanent Force units. The latter included garrison and field artillery, regiments of mounted or dismounted riflemen, and Engineer Corps as well as a South African Air Force. ${ }^{66}$

Although the specialised units were 'reserved' for the support of infantry operations within South Africa, their value as suppliers of a nucleus of trained personnel

N Tvl Comd, Box 23, file C/1 Formation of Artillery Brigade Headquarters. OC Troops - Chief of the General Staff, 7 Apr 1922.

CGS Gp 1, Box 12, file 23 S.W.Africa Native disturbance at Kalkfontein May 1922 Bondelzwart rebellion: various correspondence and Colonel van Ryneveld's Report "Air Operations Bondelzwart Revolt." p 127. 
for an expeditionary force was also recognised. In 1921, Britain had raised the question of Dominion support for her military efforts elsewhere in the world. This was a very delicate issue in South Africa. Not only was the opposition National Party vehemently opposed to the despatch of a South African contingent overseas but the Union Defence Force had also withered from a strength of 254666 during the First World War, to a meagre $39667 .^{67}$

The 1921 Imperial Conference had spoken optimistically of "a united understanding and common action in foreign policy" for the British Empire. ${ }^{68}$ The world was notified that the Empire followed a combined foreign policy. When the Empire was suddenly forced by an unexpected international crisis, to make a combined executive decision, the moment of truth weighed the formula of the 1921 Conference and was found to be wanting. A year after the conference, a series of events proved beyond all doubt that it was simply not possible to formulate one common policy for an entity subject to so many insecurities, stresses and variables as the British Empire. ${ }^{69}$

The war in Asia Minor revealed severe inadequacies in both the organisation of the Union Defence Force and the defence policy of the Empire. Britain had committed herself to provide support for Greece in her war against Turkey. However, as a result of the demobilisation and rationalisation that had taken place in after 1919, South Africa found herself to be without the military infrastructure to act in concert with the Imperial authorities. As the Permanent Force was not available for overseas service, such a contingent would be composed entirely of volunteers many perhaps coming from the Active Citizen Force. Taking as a guide, the numbers who volunteered for service during the First World War, London estimated that South Africa could furnish a force of 25000 men for service abroad. However, in the event of heavy casualties on the scale of the Western Front, the Union could not keep such a contingent in the field for more than a year. Based on previous experience, the minimum force which could be raised in response to any appeal for a contingent to serve overseas was 10000 with a strong Native Labour Corps. ${ }^{70}$ No matter how willing, South Africa could barely provide the composite brigade considered 'a fair contribution' by the War Office. ${ }^{71}$

I.J. van der Waag, 'South Africa and the War in Asia Minor, 1920 -1923', Militaria 24(1) 1994, pp 9-19.

I. Jennings, The British Commonwealth of Nations (London 1956), p 133 as quoted by D.O. Rhoodie, Suid-Afrika; van koloniale onderhorigheid tot soewereine onafhanklikheid (Johannesburg 1974), p 110.

D.O. Rhoodie, Suid-Afrika; van koloniale onderhorigheid tot soewereine onafhanklikheid, p 110.

CGS Gp 1, Box 12, file 12 Union Force for Overseas. Appendix "D" memorandum on Estimated Manpower available in the Union for military operations Overseas. 
Smuts too did not want to risk a repeat of the Rebellion, which had broken out in September 1914 on precisely this issue. Tielman Roos (NP, MP Lichtenburg) captured the sentiment in an article in Die Vaderland:

"Ons is absoluut daarteen gekant om die Unie te stoot in die byenes van Europese en Asiatiese politiek en oorloë. Dus sal die Nasionale Party veg teen die versending van ' $n$ enkele Afrikaner-Engels - of Afrikaans-sprekende - en die uitgawe van ' $n$ enkele pennie in verband darmee. Ons mede-burgers van Engels, van Hollands en van ander afstamming, is vir ons te veel wêrd om hulle daar te verloor. Ons het hulle nodig om Suid-Afrika op te voer."72

Participation was clearly a delicate issue. Dr D.F. Malan (NP, MP Calvinia) stated that South Africa was again faced with the choice of participating in another war of destruction or keeping out of a difference in which she was not involved. He denied any agreement or obligation, legal or moral, to assist Britain in her wars: "Die Dardanelle is nie ' $n$ druppel van ons bloed of " $n$ sjieling van ons geld wêrd nie, en Suidafrika (sic) behoort hom neutraal te verklaar."

Fortunately for Smuts, the whole matter simply blew over. When the call came from London, he was away in KwaZulu, remote from telegraph, telephone and wireless. In his absence no decision could be taken and upon his return the crisis at Chanak had dissipated. However, the war in Asia Minor highlighted the issue of Dominion participation in what nationalist elements described as 'Britain's wars'. The issue remained for the moment unresolved. And in any case, in 1919, the War Office had turned down numerous offers made by South Africans willing to ser ve in Russia "in view of [the impact of geography and] the time which will elapse before services could be utilized." 74

\section{Politics: domestic and Commonwealth}

The matter of imperial geography was a main concern of the Imperial Conference, held in London in October 1923, which "gave special attention to the question of Defence, and the manner in which co-operation and mutual assistance could best be effected after taking into account the political and geographical condition of the various parts of the Empire." 75 The necessity to provide for the adequate defence of both

1922.

'Geen man en geen pennie; Ons leier oor die wêreld-krisis', Ons Vaderland, 22 Sep 1922.

'Dr Malan en die Dardanelle', Volkstem, 2 Sep 1922.

World War I archive, Imperial Service Details group, Box 32, file 715/8/1 Men for Service in Russia. Telegram Troopers London - Defence Pretoria, 23 April 1919.

BPP, Cmd.1987-1923 Imperial Conference, 1923. Summary of Proceedings, p.4. 
the territories and the trade of the countries making up the British Empire was reiterated. However, the onus of the Parliaments of the several parts of the Empire to decide the nature and extent of any action that should be taken by them was also recognised and the following guiding principles were suggested:

- $\quad$ each portion of the Empire represented at the Conference, was primarily responsible for its own local defence.

•

adequate provision had to made to guard maritime communications. [The Conference stressed the "vital importance to the British Empire of safeguarding its overseas carrying trade against all forms of discrimination by foreign countries, whether open or disguised..." ${ }^{76}$ ]

- the provision of Naval bases with repair and refuel capabilities, to ensure the mobility of British fleets.

- the maintenance of the minimum standard Naval strength.

- $\quad$ the development of air forces throughout the Empire. ${ }^{77}$

Thus from 1924, the role of the Active Citizen Force was restricted to the combating of African and other uprisings within the Union. As a result of these and economic considerations, a special striking force designated the South African Field Force was organised under one commander, late in 1924. Although small and having only a small mechanised nucleus, this force was revolutionary, predating Britain's experimental mechanised force by more than two years. ${ }^{78}$ Sadly very few documents dealing with the South African Field Force are to be found at the SADF Archives, most of the records generated by the Commander of the S.A. Field Force being destroyed following an archival appraisal in $1933 .{ }^{79}$ We know nonetheless that the Field Force comprised two squadrons of the 1st Regiment, South African Mounted Riflemen and three batteries of the SA Field Artillery; ${ }^{80}$ with the 1st Regiment SAMR reorganised to include an Armoured Car Section of two cars (imported from the UK in 1925), each with two machine guns. ${ }^{81}$ This special force could be dispatched at a moment's notice to any location within the country, to deal with disturbances in a quick and clinical manner. As

BPP, Cmd.1990-1923 Imperial Economic Conference, 1923. Summary of Conclusions, 11.

BPP, Cmd.1987-1923 Imperial Conference, 1923. Summary of Proceedings, pp.16-17.

Lord Carver, The Apostles of Mobility; The Theory and Practice of Armoured Warfare (Holmes \& Meier: New York, 1979), pp 38, 48.

DC, Box 1910, file DC 251/6 Records Defence Department Destruction of Valueless Records.

Abridged Annual Report of the Department of Defence for the Year ended 30 June 1925 (Pretoria, 1926), par 10. 
events turned out, this force was not needed. The Rehoboth rebellion in April 1925 was put down with the SAAF as the only portion of the UDF employed to assist the South West Africa Administration in quelling the disturbance. ${ }^{82}$

Although rudimentary and requiring a considerable amount of building up, South Africa had in fact already established an air force and a naval capability. However, before Smuts could do very much, he lost the election held in June 1924 and the National Party came to power. This was followed by a flight of talent. Imaginative, progressiveminded officers, beset by conservative or reactionary seniors, either left the UDF (Carolus Brink, Johann Leipoldt, and possibly Hugh Wyndham) or lost their enthusiasm (Andries Brink). The same was happening in the British Army. ${ }^{83}$

The new prime minister, General J.B.M. Hertzog, retained office right up to the outbreak of the Second World War. His fifteen years in office were quieter than Smuts' proceeding term of five. Hertzog's government, initially a coalition with Labour, faced no industrial unrest and practically no violent clashes between the security forces and the black peoples occurred during this period - the only two incidences took place in South West Africa.

The co-ordination of the defence forces of the Empire together with the maximum effort, which could be expected from each Dominion in time of war, was discussed in 1923 yet in South Africa no further action was taken. In 1926, when Britain conceded Dominion autonomy, the matter was still outstanding. The question of cooperation between the South African and Imperial general staffs in the design of a South African expeditionary force had not even been laid on the table of the South African parliament. $^{84}$

For South Africa the answer was, for the moment, no. During the National Party's first term of office (1924-1929), it built up a defence force which was "calculated to protect South Africa's neutrality ${ }^{\prime \prime 5}$ and little else. The new government resigned the responsibility of colonial policing in southern and central Africa. Colonel F.H.P. Cresswell, the new Minister of Defence, set out his government's attitude to Imperial defence at the 1926 Imperial Conference. The Union Defence Force was organised for the defence of South Africa in any part of southern Africa. There was no provision, for war service outside southern Africa, and no South African citizen could be compelled to

DC, Box 1026, file DF 573/9 Rehoboth Disturbances 1925. Financial Branch circular DF 9/573,21 April 1925.

B. Bond, 'The Army between the Two World Wars 1918-1939' in D. Chandler and I. Beckett (eds.), The Oxford History of the British Army, pp 261-2. Defence, 26 Jul 1926. 
render personal war service outside these confines. Any assistance, which might have been rendered by the Union in an 'Emergency of Empire', had of necessity to be by means of volunteers. Unless, of course, special legislation was passed authorising the deployment of the Union Defence Forces beyond the borders of South Africa and other than in defence of the Union.

The policy regarding external aggression was quite distinct. In the event of South African involvement in a war outside the Union, the Active Citizen Force would not be sent. Special units would be recruited and would undergo a period of intensive training before proceeding to the theatre of war. ${ }^{86}$ This had happened in 1914 and was to happen again in 1939; and they were rapidly dispensed with once the threat had disappeared. Although political motive is clearly discernible in the change of policy, financial considerations must not be forgotten. An expeditionary force was cheaper to raise and train from scratch, than to maintain on a permanent footing.

The reserve of the Active Citizen Force for internal wars had a negative effect on the development of the Union Defence Force as a whole. Local war, necessarily shorter in duration, held the prospect of a poorly equipped and numerically weak enemy. Strong, well-equipped specialised units were therefore not needed. Hence, official policy, together with the stringent financial situation, caused a long-term lack of equipment; and this, in turn, had its effect on training.

From the middle twenties the economic pinch was felt and the Defence budget came under pressure as the UDF was made the target of further rationalisation. The original 15 military districts controlled at the end of March 1926, by 12 district staff officers, were reduced in number to 6 districts or commands, and the title of "District Staff Officer" was replaced by that of "Officer Commanding Military District."

The reorganisation of the Permanent Force necessitated the disbanding of the 1st Regiment, SA Mounted Riflemen and the transfer of its 138 ranks to the South African Police on 1 April 1926. The SA Field Force ceased to exist on 31 March 1926. The Brigade Headquarters of the SA Field Artillery was also disbanded and sections of artillery were distributed to various stations throughout the Union. The appointments of Officer Commanding, S.A. Field Force, Officer Commanding Troops, Roberts Heights, and Officer Commanding Troops, Cape Peninsula Garrison, were abolished. The Commandant, S.A. Military College, Roberts Heights, was appointed Camp Commandant, Roberts Heights, and the duties of the Officer Commanding, Cape Peninsula Garrison became the responsibility of the Officer Commanding No.1 Military District. $^{87}$ Yet, despite the cutbacks, 1926 saw independent units brigaded for the first the General Staff - Officer Commanding No.1 Military District, 12 Aug 1927. 
time: into two infantry brigades and, in Natal, a mounted brigade.

The drastic measures of 1922 and 1926, left the Permanent Force strength of the UDF at just 151 officers and 1259 other ranks by 1927. However, rationalisation was not at an end. As the global slump worsened, the effect upon the UDF became more and more severe. Difficult as the financial climate had been for the Union in the decade following 1918, the Great Depression placed even greater pressure on Defence finances. With effect from 31 December 1929, no less than 49 Active Citizen Force units were disbanded and between July 1930 and June 1934 continuous training for the Citizen Force ceased altogether. The Defence Rifle Associations did not manage to escape the austerity measures either, and in 1931 alone 54 DRAs were disbanded. The quantity of cartridges issued to DRA members was halved. This was a dangerous step. The DRAs were the second line in local defence and on a number of occasions had saved the situation when the Citizen Force had been deployed elsewhere.

As the Depression wore on, the need for further rationalisation in the Union Defence Force began to be felt and the decision to amalgamate various units of the Permanent and Coast Garrison forces was taken. By the middle of 1930, for example, the SAEC unit (PF) was attached to the South African Permanent Garrison Artillery (SAPGA) for disciplinary purposes. The unit, however, remained independent until 1 April 1931, when the SAEC personnel were all absorbed into the SAPGA. Had it not been for the Citizen Force field companies, the SAEC would have disappeared as a corps.

During the 1930-1931 financial year, defence expenditure was cut by $£ 172$ 499. Another cut followed, so that over a period of two years military expenditure was reduced by $£ 328000$. A nadir was reached in 1932 , when only $£ 736831$ was voted for Defence (table 2). In 1931, Major General A.J.E. Brink reported on the hard circumstances the UDF was facing:

"I much regret to report that the urgent necessity for economy which has curtailed the activities of most Departments of State has severely intervened with the training of Citizen Forces ... the Defence organization is called upon to curtail so large a portion of its activities." 88

The series of growing cuts in the military budgets since 1925 affected the efficiency of the UDF. There were no major weapons systems acquisitions. Structural economic change followed the development of a South African national sentiment and the demand for a South-African-formulated national and defence policy. Planned state intervention brought expansion, diversification and the development of indigenous manufacturing enterprises. Although the Iron and Steel Corporation (ISCOR) was 
established in 1928 to work South African ores, ${ }^{89}$ the impact was not yet felt. The training programme of the $\mathrm{ACF}$, in particular, was affected by the lack of equipment. Citizen Force troops could not be fully armed and equipped with uniforms; while RNVR exercises ceased. Brink expressed the fear that, if the depression continued much longer, the combat force on which the government had to rely, would be insufficiently trained and inadequately equipped for an emergency. On matters military and industrial, political leaders were poorly informed. The National Party, when in opposition, equated military and industrial power with Smuts, holism and Greater Britain. ${ }^{90}$

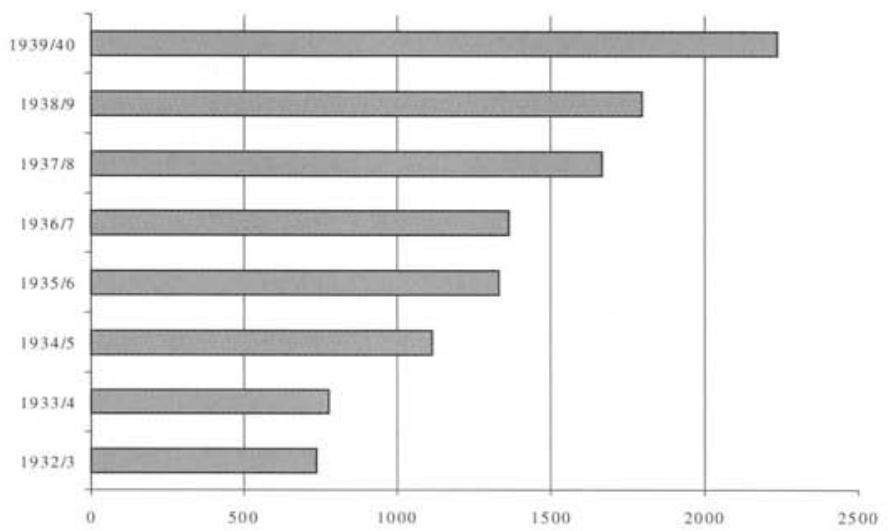

\section{Table 2: Defence Budgets, 1932-1939 (thousands of pounds).}

His assessment proved accurate when, in July 1932, the Administrator of South West Africa approached the Defence Department for assistance in dealing with Ipumbu, chief of the Kuambi tribe. The task force comprised only three aircraft equipped with seven 230-pound bombs, two armoured cars despatched from the Military College and a member of the Medical Corps. As it was, Ipumbu was deposed and the affair closed without loss of life. The Ipumbu expedition cost $£ 3316$, in comparison to the $£ 500$ spent by Defence in the suppression of the Rehoboth rebellion in 1925 . $^{91}$

One of the more successful experiments in combating the social evils following the Depression was the establishment of the Special Service Battalion (SSB) at Roberts Heights on 1 May 1933. By 30 June 1934 the SSB had a strength of 1929. Sections were later opened at Durban, Cape Town, Kimberley, Bloemfontein, African Economy (OUP: Cape Town, 1980), pp 105, 123, 126, 130. 
Uitenhage, Port Elizabeth, Kroonstad and Harrismith. Designed to provide employment and training for the many white youths left destitute by the Depression, and instil in them a military fitness and discipline which would serve them well in civilian society, the SSB was a great success and a valuable source of trained personnel to the UDF, other state departments and the state-controlled manufacturing sector, in subsequent years. ${ }^{92}$

In addition to the Special Service Battalion, a special short service unit consisting of 500 men were given training for a period of three (later increased to six) months. This unit, the Pioneer Battalion, was established with effect from 1 January 1935 as a unit of the Permanent Force and played the same social role as that of the SSB, with the exception that the age limit was set between 18 and 30 years, and all candidates were to be unmarried. Unlike the SSB, no set standard of education was demanded. The recruits for the Pioneer Battalion were of a poorer, less-educated type, who all their lives were "brought up in necessitous circumstances, badly fed, clothed, accommodation and not used to money". ${ }^{93}$ The UDF hoped to discipline them, and then find them employment after the end of their period of service, so that they would become accustomed to regular income and strive for better prospects in life. The Pioneer Battalion, however, attracted "really vicious types" and "was very nearly a failure." ${ }^{.94}$ General Andries Brink also recognised the danger that they would return after their service, to their former environments, develop a spirit of dissatisfaction with the government, and ultimately become a potential source of danger to the State.

Brink proved pretty much in touch with the situation. The Railway Board, in fact, undertook to find employment in the South African Railways and Harbours (SAR\&H) for 500 members of the Pioneer Battalion, each year. Many refused State employment, both with the Railways and in other government schemes. Of the 66 details discharged during the first week of September 1935, only twelve accepted employment on the SAR \& H. Four others went to work on the Vaal Dam Irrigation Works and a further three were placed in private employment. The remaining 47 either refused employment or re-engagement with the Special Service Battalion, and returned home to take up farming or eke out a private existence on their own. However, it is true that many of the 47 were under 21 years of age and not in possession of a Standard VI certificate, and therefore could not be considered for employment with the Railways or enlistment with the SSB. All in all, the scheme was not the resounding success it has perhaps claimed to be. ${ }^{95}$

During the course of 1934, the South African economy began to show definite

W. Otto, Die Spesiale Diensbataljon (Pretoria 1973), pp 9-10.

Archives of the General Officer Commanding, Union Defence Forces (hereinafter GOC), Box 15 , file GOC 60 Pioneer Battalion. 
signs of an upward trend. In fact, so much so, that a significant increase in the Defence budget was approved for the first time since 1924, and Brink could announce that the UDF would once again transform into a military organisation of modern standing.

\section{New threat and a change in policy}

After 1930, the international climate had changed dramatically with the weakening of colonial authority in the French mandate territories and Gandhi's subtle acts of rebellion in India. France, perceived as a possible threat to British Africa in the 1920 's, had bound herself to Britain in the next decade, in view of common colonial problems and a fear of German interest in regaining some of her lost colonial possessions. Furthermore, international stability deteriorated rapidly with the decline of the European-parliamentary liberals and the rise of authoritarianism in central and southern Europe.

The focus of British Imperial defence, as a result, swung from the other Colonial Powers (France, Belgium and Portugal) to the Fascist Powers. In fact, as early as 1926, the Intelligence Section in the office of the Chief of the General Staff, in collaboration with MI5, had became involved in the surveillance of German and Italian agents in southern Africa. ${ }^{96}$

In South Africa, with a recovery in the economy and a new coalition government in power, including both Hertzog and Smuts, who received the Justice portfolio, a number of changes were made with regard to the Union Defence Force. Advocate Oswald Pirow, the new Minister of Defence who described Hitler as "perhaps the greatest man of the last thousand years", ${ }^{97}$ began the specialisation within the South African General Staff. General Andries Brink was appointed to the new post of General Officer Commanding the UDF and Secretary for Defence in 1933. The autocratic and stubborn Brigadier General (Sir Pierre) van Ryneveld, for whom the likes of George Brink had no affection or respect, ${ }^{98}$ succeeded as the new Chief of the General Staff, while his old post (Director Air Services) was abolished and replaced by a smaller Directorate of Civil Aviation. In the same year, a Technical Services Directorate was established to relieve the Quartermaster General of all his technically orientated duties; and the General Staff Section at DHQ passed under the control of the new Director of Military Operations and Training. These changes resulted in the formation of five major sections at DHQ under the overall control of the Chief of the General Staff: Director

CGS Gp 1, Box 47, file 71 Intelligence Contré Espionage (MI5). Chief of the General Staff Colonel Sir Vernon Kell, 26 Aug 1926; and MI5 - Chief of the General Staff, 25 Sep 1926.

J. Crwys-Williams, A Country at War, 1939-1945; The Mood of a Nation (Rivonia 1992), p xix. 
Military Operations and Training; Adjutant General; Quartermaster General; Director Technical Services; and the Director Medical Services.

These appointments proved to be a turning point in the history of the UDF. Pirow's first defence budget reflected a tremendous increase on that of the previous year, and military expenditure climbed steadily right up to the outbreak of the Second World War. The guiding lights were Pierre van Ryneveld and George Brink. Only weeks after the formation of the new cabinet, it was he who convinced Pirow of the need to expand the UDF. Although a direct attack on South Africa was improbable, there was the omniscient internal unrest and the onerous imperial commitment. In the event of a world war, the defence of the Cape Sea route would largely fall to South Africa; and the potential threat on the northern borders by black Africans of the surrounding territories could not be ignored. Van Ryneveld grabbed at any argument for expansion, and particularly of the air force. Pirow was in agreement and made the issue his own. ${ }^{99}$

After the 1933 Imperial Conference, South African forces were no longer confined to actions within the Union and as a result of this change in policy, the Union Defence Force was expanded. By the middle of 1934 and only a year after the inception of the Coalition government, quite a reorganisation of the Union Defence Forces had taken place. Coastal defences were considerably improved. The Coastal Artillery Brigade made its appearance in Cape Town, comprising various units across the country including an Armoured Train. Aircraft, from an expanded air force, were permanently stationed at the defended ports of Cape Town and Durban, to augment the fixed and movable armament. A coastal defence fighter-bomber squadron was also called into being in 1938, for the defence of the Cape Peninsula including the RN base at Simon's Town. ${ }^{100}$ The first three of the converted JU 86 s arrived at Cape Town on 18 September 1939, from when this squadron assisted the Royal Navy in the defence of the Cape sea route. $^{101}$

The Active Citizen Force was increased by the addition of eight new infantry battalions organised according to country districts and a field organisation of six brigades was formed into "forces" corresponding to divisions. ${ }^{102}$ At Van Ryneveld suggestion the ACF was expanded to 12 urban and 12 rural regiments - divided linguistically on a 5050 basis. Almost four hundred Bren guns were order from Britain in 1935, two years later only 15 had been delivered. Nonetheless, after five years, Pirow envisioned a

G.E. Visser, Die Geskiedenis van die Middellandse Regiment, 1934-1943 (Unpub MA dissertation, UNISA, 1983), p 10.

GOC UDF, Box 15, file GOC 52/4 Grant of assistance to Royal Navy.

'SA Forces in the Second World War', Militaria 19(3) 1989, p.39.

GOC, Box 15, file GOC 57 Report on Defence Organisation since inception of Coalition Government 1933. 
trained and equipped PF and ACF of 56000 and a national reserve of 100000 men. ${ }^{103}$

However, the Admiralty was deeply concerned with the discontinuance of the hydrographic survey work in South African waters and much to their consternation the PROTEA was decommissioned on 1 May 1933, ${ }^{104}$ A year later, the SA Naval Service was disbanded. The RNVR was increased in strength, reaching almost 1000 in 1936 , over six sub-divisions and three flotillas. But, as far as Britain was concerned, this was poor compensation for the expansion of the South African Navy. Britain was welcome to pay for her rule of the waves but South Africa would focus on the protection of her harbours and shoreline. South Africa, on the other hand, wanted to invest more in coastal defence. As far as the British were concerned this was an over-investment.

The British saw other priorities and the discrepancy caused problems. London believed that in the matter of defence "it is essential to take into account the mentality of South African ministers and specially of Pirow." The British High Commissioner in Pretoria warned London not to "appear to belittle South Africa's place in the picture" of Imperial defence and reminded them that "the big thing rather than the adequate but unspectacular" appealed to Pirow and apparently also to Smuts. ${ }^{105}$ Vice Admiral Sir E.R.G.R. Evans of the Africa Station repeated these sentiments. Pirow was "a man of action" with little use for half measures. Andries Brink was "no lover of England or the Royal Navy" and was expected "to support any suggestion for doing as little as possible." While Van Ryneveld

"knows and cares little about the Navy, but is an enthusiastic airman. He will be only too ready to seize on any remark about mobility to press for an expansion of the Air Force to the exclusion of all else." 106

Nonetheless, Evans believed he "had a great deal in common" with Pirow, his "greatest friend in the Southern Hemisphere" whose "company to me was like a glass of champagne after a successful Admiral's inspection." ${ }^{107}$ He was the first British admiral to write in Afrikaans and Pirow could say with much justification in the House of Assembly that: "Thanks to Admiral Evans, our relationship with the Africa Squadron is more

F.J. Jacobs, Tussen twee wêreldoorloë' in R.J. Bouch (ed), Infantry in South Africa, 1652-1976, p 131; and J.A. Brown, War of a Hundred Days, p 30.

DC, Box 1098, file 4/58 Disposal of on Paying off HMSAS PROTEA. Secretary of State for Dominion Affairs - Minister of External Affairs, Pretoria, 7 Dec 1932; and Vice Admiral E.R.Evans, Commander-in-Chief Africa Station - Chief of the General Staff, 1 May 1933.

PRO: DO 119/1052 High Commissioner for United Kingdom, Pretoria - Secretary of State, London, 17 Jul 1935.

PRO: DO 119/1052 Evans - High Commissioner for Basutoland, Bechuaunaland Protectorate and Swaziland, 10 Sep 1935.

Evans quoted in R. Pound, Evans of the Broke, p 219. 
cordial than it has been in our history." ${ }^{108}$ Pirow's slide from favour was gradual. Eyebrows were raised during the Spanish Civil War, when he visited General Franco's headquarters instead of the Republican Government, and later when he visited Hitler without disclosing the content of their discussions to the world.

Pirow's five year plan, as far as the SAAF was concerned, included the training of a thousand pilots by flying clubs and schools throughout the Union by 1942, as well as the purchase of new aircraft some of which were to be built under licence in South Africa. A new operational air station was built at a new site to the east of Zwartkop Air Station, home of the Central Flying School. An aerodrome, named Waterkloof Air Station, was opened on 1 August $1938 .^{109}$ Here one can clearly see the work of Van Ryneveld, the 'air minded' Chief of the General Staff. Furthermore, after 1933, more than half of the South Africans sent to Britain for training were airmen, whereas in the preceding period none had been sent (figure 1).

However, as far as an expeditionary force was concerned Pirow stated that his government would not commit herself in advance: the circumstances of the emergency would determine South African participation. Pirow did, however, add that it was possible, even probable, to assume that the South African government would be willing to assist in the defence of British interests in East Africa but then only if the white populations were threatened. Furthermore, most politicians and soldiers accepted that the defence of South Africa from overland attack "should be undertaken as far to the north of her boundaries as her military strength and resources and the situation [would] permit." ${ }^{110} \mathrm{He}$ emphasised that under no condition, would the Union Defence Force be available for service outside Africa. ${ }^{111}$

This, however, was still an important concession on the part of Hertzog's government. South Africa's 'wartime frontier' had shifted to East Africa. No sooner had this new defence policy been laid down, than it was put to the test following the Italian invasion and annexation of Ethiopia in May 1936. ${ }^{112}$ On 4 February 1936, while the war in Ethiopia was raging, the government vocalised the policy as follows:

"the maintenance of international peace in such manner that the obligations

Pirow quoted in R. Pound, Evans of the Broke, p 237.

Dave Becker, Waterkloof 50 (Pretoria 1988), pp 1-3.

J.J. Collyer, The South Africans with General Smuts in German East Africa, 1916, p 273.

CGS Gp 1, Box 62, file G.93 South African aspects of Imperial Defence. Minutes of the 259th Meeting of the Committee for Imperial Defence held on 24 Jul 1933; and Minutes of Meeting held on 24 Jul 1933 to consider certain questions relating to South African Defence.

CGS Gp 2, Box 498, file G.898 Ethiopia. Consul General, Sweden - Secretary for External Affairs, 30 Oct 1935. 
which the Union assumed by becoming a member of the League of Nations will be loyally carried out, and the freedom and interests of the State will be faithfully and honourably safeguarded." ${ }^{113}$

Pirow, furthermore, was pressured to address the matter of South African participation in foreign wars per se. He told the House:

"We are not bound directly or indirectly to take part in any war, in Africa, or elsewhere. We shall not take part in a war except when the true interests of South Africa make such participation inevitable. We as a Government will not even take part in an apparently inevitable war except after the people of this country through their representatives in Parliament have with the greatest possible measure of unanimity, given us an unambiguous mandate to that effect." 114

Concurrently, the South African General Staff appointed Major General Collyer, who in his retirement was working on a history of the South West campaign, to produce a textbook on the 'lessons' of First World War. The East African focus was tacit proof of South African recognition of her 'imperial obligations'. Aimed at instruction for officers at the Military College, Collyer hoped to prepare South African officers for service on "the continent of Africa." 115 The South Africans with General Smuts in German East Africa appeared only months before the outbreak of the Second World War, too late to influence many of the officers who sent to that theatre. And in any case, many of his 'lessons', in particular those concerning air power and mechanical transport, were misinformed.

\section{Political opposition and mobilisation}

Gradually the Union Defence Force was dragged fully into the party political arena. The event, which brought the situation to a head, was the appointment of Andries Brink, who, through no doing of his own, was associated with Jameson's Raiders, as Chief Commandant of Commandos on 31 March 1937. ${ }^{116}$ A year later, Frans Erasmus (HNP, MP Morreesburg), the shadow Minister of Defence, lambasted Pirow for not modernising the Commandos and for effectively splitting the Union Defence Force by placing it under two chiefs: Brink and Van Ryneveld. This, in Erasmus' mind, reduced the commandos to the "second line of troops"; whereas the National Party wished to

Debates of the House of Assembly, 4 Feb 1936, col 169.

Debates of the House of Assembly, 4 Feb 1936. 1916 (Pretoria, 1939). 
continue the old Republican tradition of the Commandos, as a peoples' army of the first line. This had been cardinal to the two resolutions the Cape Congress of the National Party had passed on defence in September 1923. Erasmus stated in 1938:

"I cannot use sufficiently strong language to express my disapproval of the Minister having brought about a split in the Defence Force. If a person is not suitable for his position, why then must you split up the Defence Force owing to a man who is unpopular with the Boer Commandos? Why do you not get rid of him?" 117

The opposition Purified National Party - in the person of N.J. van der Merwe (HNP, MP Winburg) - believed that the money voted for by Parliament in the Defence budget was not for the defence of South Africa, but for the defence of the Empire. It was, he said, in the interests of the country for the Union Defence Force to feel that it had the whole country behind it, and that the question of defence should not become a party political matter. He did not believe that the people as a whole stood behind the defence force, as it did not yet bear "a truly peoples' national character amongst our public" and:

"all we have to-day appears to be nothing else than an outward show, nothing else but window-dressing ... When we go to Roberts Heights then we have a caricature of a miniature Aldershot." 118

The camp layout and colonial architecture lent a British atmosphere. A recent example was the Artillery School building at Roberts Height, which was completed in January 1936 at a cost of fifty thousand pounds. ${ }^{119}$ The pill was bitterer to swallow when new buildings were opened with British pomp and ceremony, as was the case of the new military hospital opened at Roberts Heights in October 1930 by Princess Alice, wife of the Governor General and a granddaughter of Queen Victoria. British pattern led to British atmosphere. An attempt to dilute this atmosphere was taken in December 1938, when, in the heat of the Trek Centenary, General J.C.G. Kemp, the old rebel leader, announced unexpectedly and to the consternation of the English-speakers that Roberts Heights would henceforth be called "Voortrekkerhoogte".

Criticism also came from the Smuts supporters on the government benches. S.F. Waterson (MP South Peninsula) questioned the Minister of Defence as to what the government was doing in regard to defence. Pirow made two statements, one in 1934 and one in 1936, but had offered no additional information since then. His five-year plans would, after all, mature in 1939 and 1941, and he had given no progress report. ${ }^{120}$ What

Debates of the House of Assembly, 7 Sep 1938, col 2309. 
was more, according to Lt Gen Goerge Brink, "by 1937 the Government had not informed the General Staff what its Defence policy was." ${ }^{121}$

During 1938 Pirow was pressed to state for what contingencies the Defence Department should plan and on 7 September in Parliament he listed the factors that made South African participation in an international war unique. Firstly the composition of the European population, with neither section prepared to support a defence policy aimed exclusively at making soldiers out of the youth of the country. "Any approach to our problem of national defence," he reassured parliament, "must be from a purely South African angle, and must take into consideration factors which are not found in any other portion of the Commonwealth, or which, if found, are of minor importance. The first of these factors is the comparison of our European population. With sixty per cent of the population Afrikaans-speaking no defence policy will command the support of the bulk of the people of the Union unless scope is explicitly confined to the protection of South Africa and her vital interests." 122 Black South Africans were still left out of the equation.

Furthermore, Southern Africa could never become the main theatre of a major war. And, due to geography, a large-scale gas or air attack on the civil population need not be seriously considered. South Africa's manpower resources, when compared with those of even second-class powers, were very limited and, in spite of all its potential wealth, South Africa had much poverty and there was a definite limit to what the country was prepared to spend on defence. However, her maximum effort would not have to be made until six months after the outbreak of hostilities and this allowed a period for intensive preparation. South Africa also faced the relative certainty that her troops would be called upon to fight a mobile war. Precisely a year later the country was at war with Germany.

For the official opposition matters were not as cut and dry. Erasmus, the shadow minister, used the opportunity to articulate the National Party's stance:

"At the moment my point is that we are in a comparatively safe position. South Africa has no enemies. The only danger we are in, and the only enemies that we have, are on account of our association with Great Britain. ... The first way in which this association with Great Britain will involve us in a war is if we decide to take part in a war in which she is engaged." 123

According to Erasmus, South Africa could also be drawn into a war in at least two other ways: in connection with the Smuts-Churchill Simon's Town Agreement and

Debates of the House of Assembly, 7 Sep 1938, coll 2293-2295. 
the association of the Hertzog government with plans for the defence of colonial territories to the north of South Africa. The latter "carried the implication of joint defence co-operation with the country [i.e. Britain] whose territories they were." ${ }^{124}$ He went on:

"I hope that the Minister in future ... will keep his eyes less on the interests of England and the British interests at the Equator, and more on the interests of South Africa, for her self-defence. I hope that he will keep his eye more on our boundaries, not on the boundaries of Abyssinia, but the boundary of the Limpopo."125

The Purified National Party was not opposed to expansion in the Union Defence Force. They were willing to vote money for the building up of the UDF in the spirit of the Defence Act of 1912 - that is to enable South Africa to defend herself. In short, the Nationalists wanted to build up the UDF to protect South Africa's neutrality, not to partake in European wars.

Smuts, who was actually the Justice minister, stressed the contrary. In the event of a war against the Axis, South Africa's first line of defence would lie outside the country. And when the war came a new attestation form, requiring volunteers for service 'anywhere in Africa', was introduced. South Africa's 'wartime frontier' was Kenya, guarding against Italian expansion in East Africa. Unsurprisingly this was the first theatre to which South African troops were sent.

Many senior officers supported Smuts, who was a mentor to many of them including Van Ryneveld. In fact the relationship between Smuts and Van Ryneveld was described by the official historians of the Second World War as being "an almost David and Jonathan association."126 Furthermore, conversations with military attachés, visits abroad, such as that undertaken by George Brink in 1937, and meetings with foreign counterparts, including the CIGS and the British naval personnel at Simon's Town - Evans had a considerable influence upon George Brink, for example - convinced them that war was inevitable and that South Africa needed a modern defence force. ${ }^{127}$ Not all agreed the potential enemy. Smuts and George Brink thought Italy in Africa and possible Germany in Europe. Van Ryneveld and 'most of his staff' were fixated with an Italian invasion of southern Africa, with the Italian's possibly enjoying co-operation of

As quoted by Newell M. Stultz, The Nationalists In Opposition, 1934-1948 (Cape Town and Pretoria, 1974), p 47. See also G.D. Scholtz, Hertzog en Smuts en die Britse Ryk (Kaapstad 1975), pp 49 et seq.

Debates of the House of Assembly, 7 Sep 1938, col 2310.

H.J. Martin and N. Orpen, South Africa at war; military and industrial organization and operations in connection with the conduct of the war, 19391945, p. vi.

Introduction by Lt Gen G.E. Brink to N. Orpen, East African and Abyssinian Campaigns, p viii; and C. Birkby, Uncle George, p 74 et seq. 
Britain's oldest ally, Portugal. Of particular danger was Italy's Cant Z 1007b. This aircraft, with a range of over 2000 kilometres, was capable of reaching the Witwatersrand from Madagascar. ${ }^{128}$ The SAAF, as far as Sir Pierre was concerned, required fighters capable of an adequate defence. An elaborate Z-plan was devolved in which South African forces would seize Lourenço Marques and so deny the enemy a base from which to strike at the industrial heartland of South Africa. ${ }^{129}$

Yet of the issues highlighted during the first round of defence planning in 1933, some had been addressed others ignored. These related to South Africa's probable task; what forces were required to cope with the task; how these forces were to be armed and equipped; and how they were to be trained. ${ }^{130}$

As regards South Africa's probable task, Pirow took up a position somewhere between Erasmus and Smuts. South Africa would only go to war, he said, if it were vital for the protection of South African interests and only if the people gave the South African parliament an unambiguous mandate. South Africa would assist Britain if attacked by Germany but would remain neutral should Britain and France declare war against Germany. This implied deployment in Africa at best. Nonetheless, South Africa's lack of response during the Munich Crisis, while perhaps predictable, remained a severe disappointment in London. Hertzog had refused to issue the required proclamations for the RNVR. And, as a result, the British Admiral at Simon's Town decided, in the event of this happening again, to call up all retired Royal Navy and Royal Naval Volunteer Reserve personnel in South Africa, irrespective of whether they were members of the South African Naval Service War Reserve. ${ }^{131}$ This, in the end, was unnecessary and, interestingly, the updating of the records of the Permanent Force Reserves commenced in February 1939. ${ }^{132}$

In a controversial book published in 1960, Eric Hartshorn, brigade major of the $1^{\text {st }}$ SA Infantry Brigade Group and later commander of the $1^{\text {st }}$ Transvaal Scottish, exposed a plot by a handful of ACF officers to take extreme steps in the event of Parliament voting for neutrality. Convinced that the whole of the UDF would not fight should South Africa go to war and having no confidence in "the majority of Senior Regular Officers", they hatched a plan to mobilise the Witwatersrand Citizen Force and make for Natal. There was a similar plot in the SAAF. According to an anonymous

J.A. Brown, War of a Hundred Days, p 30.

C. Birkby, Uncle George, pp 95-6.

Debates of the House of Assembly, 7 Sep 1938, coll 2296-2300.

PRO: Admiralty (hereinafter ADM) 199/2352 Africa Station War Book. Commander-inChief, Africa Station - Commanding Officers, H.M. Ships, 9 Feb 1939.

I.J. van der Waag, Military Record Preservation in South Africa, 1914-1992: a history of Directorate Documentation Service,' Militaria 23(4) 1993, p 22. 
squadron leader:

"We had every Nationalist supporter in the Air Force carefully marked ... We had all our aircraft ready with every scrap of ammunition that we could carry and we were going to fly every aircraft in South Africa to Rhodesia ... The few British fighters in Rhodesia were actually standing by to escort us in." 133

Secondly, in the event of South African participation in a foreign war, specialised units would be recruited and they would undergo intensive training prior to despatch to the theatre of war. ${ }^{134}$ And, as in the case of the First World War, they would be demobilised following the peace settlement. It was thought that an expeditionary force was cheaper to raise and train from scratch, than to maintain on a permanent footing. The defence plan launched in the mid-thirties was to raise nine Citizen Force infantry brigades. By September 1939, 26 infantry units as well as the Special Service Battalion made up these nine brigades. In addition to this infantry core, three field artillery brigades and two field batteries, two medium batteries, two light batteries, an antiaircraft and anti-tank battery, two artillery batteries for the Coast Garrison, seven heavy batteries of Coast Garrison artillery, and various supporting elements - including the SAEC, SAMC and SACS - were provided for. The 1st Field Survey Company (ACF) was established with effect from 1 April 1938. ${ }^{135}$ Three more field companies, together with no less than 21 other ACF units, were established with effect from 1 April $1939^{136}$ and, by September of that year, there was a field company to support each of the nine infantry brigades. ${ }^{137}$ Many of these units existed only on paper or very under-strength. ${ }^{138}$

Thirdly, despite the presence of a sizeable and largely state-controlled industrial complex, the Union Defence Force experienced shortages in arms and equipment throughout the inter-war years. Such equipment as there was, was obsolete. The result of poor planning and financial stringency, the defence force had to be built up almost from the beginning. The focus upon short, local wars against poorly equipped enemies negated the need for specialised units. Most objectives could be achieved with relative ease and in a cost-effective manner by the air force, which provided the firepower and mobility and had a champion in the person of Pierre van Ryneveld, the

E.P. Hartshorn, Avenge Tobruk (Purnell: Johannesburg, 1960).

CGS Gp 2, Box 141, file CGS 242 Chap 1 Formation of the Engineer Corps General. Minute CGS 242 (G.L.) dd 12 Aug 1927 from the Chief of the General Staff to the Officer Commanding No.1 Military District.

Routine Order 240 of 28 May 1938.

Routine Order 427 of 8 July 1939.

F.J. Jacobs, Tussen twee wêreldoorloë' in R.J. Bouch (ed), Infantry in South Africa, 1652-1976, p 132 .
} 
Chief of the General Staff. In May 1937, at the prodding of George Brink and others, Pirow set up a War Supplies Board under Colonel F.R.G. Hoare, the Director of Technical Services. The Board established a factory for the manufacture of small-arms ammunition, in collaboration with Imperial Chemicals Industries, and this came into production at the end of 1938. Bren guns were adapted to fire grenades and spare barrels for howitzers of varying calibre were manufactured. ${ }^{139}$

Following the vote in the Assembly on 6 September 1939 and his appointment as prime minister, Smuts immediately went about putting the war and supply on a business-like footing. He became commander-in-chief with Van Ryneveld confirmed as his chief of the general staff. Collyer was recalled from retirement and appointed as Smuts' military secretary; while C.H. Blaine, appointed with the rank of Brigadier, replaced Pirow's protégé as Secretary for Defence. Colonel Piet de Waal, a grandson of Louis Botha, became Director General of Operations and flew to Nairobi to ascertain what assistance South Africa could provide in the event of an Italian offensive. Smuts promised to have a brigade group ready for East Africa by June 1940. This was to include three infantry battalions (one of which was motorised), one artillery brigade, engineers, signals, medical, technical and "Q" services, and line of communications personnel together with three air force squadrons. A Company of armoured cars would follow, once these were produced in South Africa. By the second half of 1940, the Ford plant in South Africa had assembled almost twenty thousand trucks and the aircraft construction programme in the SAAF workshops included Wapitis, Avro Tutors, and Hawker Hartbeest. ${ }^{140}$ George Brink, Director of Army Organisation and Training since November 1937, was the first South African commander to take troops into the field against Italy as an enemy in 1940.

Under the direction of the chairman of ISCOR, Dr H.J. van der Byl, material and equipment of all kinds was produced within a few months and largely from South African resources. ${ }^{141}$ The engineering workshops of the goldmines and the Railways and Harbours became arsenals for war, and the Industrial Development Corporation was established in 1940 to facilitate the development of new industrial enterprises. ${ }^{142}$ Small arms ammunition, artillery shells, mortars and howitzers were produced, soon for export to other allied countries thanks to the increased output of high-grade steel from

N. Orpen, East African and Abyssinian Campaigns (Purnell: Cape Town and Johannesburg, 1968), pp 5-7; and J.A. Brown, War of a Hundred Days, pp 42, 69.

The archives of the Director General War Supplies comprise 147 volumes and contain a wealth of material on divergent matters, including Commonwealth co-operation in the manufacture and supply of material during the Second World War. 
ISCOR. $^{143}$ In 1945, ISCOR produced no less than 866107 metric tons. ${ }^{144}$ The production of trucks and armoured cars allowed the mechanisation of several units. By September 1940, the South African Ford plant alone assembled 18349 lorries, all for the war effort and some converted into mobile dental units, bath and laundry units, map printing vehicles and bacteriological laboratories. ${ }^{145}$

This was a remarkable achievement. More so, as most of the skilled staff at ISCOR, being German contract labour, was interned at the outbreak of hostilities. As yet untrained South Africans kept the works going. Then many of them were enlisted into the armed forces and replaced by women and black workers. Van der Byl and his executives are reputed to have rolled up their sleeves and taken a turn in the works. Nonetheless, South African industry was much better equipped in 1939 to meet the challenges of war than it had been in 1914. Rapid expansion to meet wartime demand was proof of a broader base and greater maturity. ${ }^{146}$

Fourthly, the long-term lack of equipment between the world wars affected training. Only after the Munich Crisis did training assume a new urgency. In 1936, for example, Major Schoon of the South African Engineer Corps reported that "the field companies held totally inadequate stores for their efficient training" ${ }^{147}$ and as a result, most Sappers were simply trained as infantry. ${ }^{148}$ This problem was not unique to the Engineers. No medical training had taken place since the closure of the Medical Training School in 1919. ${ }^{149}$ Furthermore, no physical training took place in the Union Defence Force between 1923, when the last British instructors left Roberts Heights, and 1937, when George Brink highlighted the omission. Pirow, having seen the emphasis placed by Germany and other European states upon physique, bought the idea although regular PT was only re-introduced in May $1939 . .^{150}$ After a vigorous recruiting programme, instructors were trained to train the 137000 recruits. Eventually a quarter of million

Australia, for example, purchased South African armoured fighting vehicles and 3.7-inch howitzers.

See R. Dummett, 'Africa's strategic minerals during the Second World War', Journal of African History 26(4) 1985, pp 381-408.

J.A. Brown, The War of a Hundred Days; Springboks in Somalia and Abyssinia (Ashanti: Johannesburg, 1990), p 69.

D. Hobart Houghton, The South African Economy, pp 126-127.

CGS Gp 2, Box 141, file G 242 Chap 2 Formation of the Engineer Corps General. Report by Major Schoon on "South African Engineer Corps", 28 Aug 1936.

Orpen and Martin, Salute the Sappers, I, p 9.

DC, Box 1411, file 70038 Reorganisation of the Department (Medical Section). Director Medical Services - Secretary for Defence, 31 Jul 1919.

C. Birkby, Uncle George, p 71. 
white men were mobilised, together with several hundred thousand women and blacks for the auxiliary services.

As a result of Pirow's pro-German sentiments, the Hertzog government's views on African defence and the nature of theatre, the Union Defence Force, like many militaries in 1939, was not ready for the Second World War. Pirow, castigated as the 'Little Hitler of South Africa', was lambasted in the months following the declaration of war for doing nothing. ${ }^{151}$ A private in the Transvaal Scottish wrote:

"The only thing this particular Minister is known for is the equipping of the SA Army with 'bushcarts'. Some of these stand outside the military college at Roberts Heights as a remembrance of the futile work of an absolutely incompetent Minister." 152

This was a little unfair. South Africa's defences had reached a peak in 1939 and were in a better state of preparation than in any other time in her history. Pirow can at most be blamed for doing little with regard to an expeditionary force, something on which the cabinet itself was divided. Only in September 1938, at the time of the Munich Crisis, did the whole cabinet subscribe to a Defence Policy. In the words of Pirow, himself, South Africa

"would unhesitatingly support Britain in the - unlikely - event of her being attacked by Germany ... If, however, Britain and France were to declare war on Germany about happenings in Central or Eastern Europe, South Africa would remain neutral. In September 1938 ... General Smuts and the whole Cabinet, without exception, subscribed to this Policy. I reorganised the Defence Department to meet the above contingencies." ${ }^{153}$

F.S. Crafford, Jan Smuts; 'n Biografie (Edina: Kaapstad, g.d.), pp 317-318 and, for a semi-autobiographical defence, see Oswald Pirow's biography of Hertzog, James Barry Munnik Hertzog, pp 218-220. War, p 69. 